University of Nebraska - Lincoln

DigitalCommons@University of Nebraska - Lincoln

Nebraska Cooperative Fish \& Wildlife Research Nebraska Cooperative Fish \& Wildlife Research Unit -- Staff Publications

1997

\title{
Effect of Red Imported Fire Ant Envenomization on Neonatal American Alligators
}

Craig R. Allen

U.S. Geological Survey, callen3@unl.edu

Kenneth G. Rice

U.S. Geological Survey

Daniel P. Wojcik

U.S. Department of Agriculture

H. Franklin Percival

U.S. Geological Survey

Follow this and additional works at: https://digitalcommons.unl.edu/ncfwrustaff

Part of the Other Environmental Sciences Commons

Allen, Craig R.; Rice, Kenneth G.; Wojcik, Daniel P.; and Percival, H. Franklin, "Effect of Red Imported Fire Ant Envenomization on Neonatal American Alligators" (1997). Nebraska Cooperative Fish \& Wildlife Research Unit -- Staff Publications. 50.

https://digitalcommons.unl.edu/ncfwrustaff/50

This Article is brought to you for free and open access by the Nebraska Cooperative Fish \& Wildlife Research Unit at DigitalCommons@University of Nebraska - Lincoln. It has been accepted for inclusion in Nebraska Cooperative Fish \& Wildlife Research Unit -- Staff Publications by an authorized administrator of DigitalCommons@University of Nebraska - Lincoln. 
This article is a U.S. government work, and is not subject to copyright in the United States.

Journal of Herpetology, Vol. 31, No. 2, pp. 318-321, 1997

Copyright 1997 for the Study of Amphibians and Reptiles

\section{Effect of Red Imported Fire Ant Envenomization on Neonatal American Alligators}

Craig R. Allen, ${ }^{1}$ Kenneth G. Rice, ${ }^{1}$ Daniel P. WoJCIK, ${ }^{2}$ AND H. FRANKLIN PERCIVAL, ${ }^{1}$ Florida Cooperative Fish and Wildlife Research Unit, Biological Resources Division, US. Geological Survey, and Department of Wildlife Ecology and Conservation, Unizersity of Florida, Gainesville, Florida 32611, USA, 2United States Department of Agriculture, Agricultural Research Service, Center for Medical, Agricultural, and Veterinary Entomology, P.O. Box 1465, Gainesville, Florida 32604, USA.

Alligator populations in the southeastern United States have substantially recovered since the late $1960 \mathrm{~s}$ when they were placed on the federal Endangered Species List (Joanen and McNease, 1987). In Florida, both early age class and adult animals currently are harvested for commercial and recreational purposes (Hines and Abercrombie, 1987). In addition, the alligator is ecologically important as a keystone species and as an indicator of wetland health (Mazzotti and Brandt, 1994).

Recently, the nonnative ant Solenopsis invicta (the red imported fire ant) has surfaced as a potential threat to alligator populations. Solenopsis invicta is a relatively new (approx. $65 \mathrm{yr}$ ) non-indigenous addition to the invertebrate fauna of the United States. Solenopsis invicta is an opportunistic generalist; its main food items are other invertebrates (Wilson and Eads, 1949), but vertebrates also may serve as prey (Allen et al., 1994). Pipping young of oviparous vertebrate species may be especially vulnerable to direct mortality (Allen et al., 1994 and references therein), but indirect 
effects also are possible (Allen et al., 1995; Guiliano et al, 1996; Pedersen et al, 1996). Indirect effects have been documented for juvenile northern bobwhite (Colinus virginianus), including lower survival rates and body mass gain (Giuliano et al., 1996) and behavioral changes including reduced time spent foraging and resting (Pedersen et al., 1996). Anecdotal reports of $S$. invicta impacting herpetofauna are plentiful, but published evidence is limited (e.g., Landers et al., 1980; Mount, 1981; Mount et al., 1981; Freed and Neitman, 1988; Donaldson et al., 1994; Montgomery, 1996).

Since its introduction to Mobile, Alabama, S. invicta has spread throughout the southeastern United States (Vinson and Sorensen, 1986), and its range now completely overlaps the range of the American alligator. Solenopsis invicta prefers disturbed sites with full to partial sun exposure for nesting (Tschinkel, 1988). In inundated marsh systems, alligator nests appear to meet the nesting requirements for S. invicta. Alligators generally nest in fairly open microhabitats, and their clutch cavities are raised above the substrate (Deitz and Hines, 1980). In habitats that are saturated with water, alligator nests may provide sufficient exposure and disturbance to become the preferred nesting location for fire ants. Surveys of central Florida lakes by the authors indicate that up to $20 \%$ of alligator nests in marsh habitats contain colonies of S. invicta.

We tested the hypothesis that envenomization by $S$. invicta has an impact on hatchling alligator survival and body mass. Additionally, we tested whether eggs of the American alligator were attractive food sources for $S$ invicta. Whereas our tests were restricted to eggs and young of alligators, our results may be more generally applicable to oviparous herpetofauna.

Alligator eggs were collected as part of an ongoing long term study from Lake Apopka in central Florida (see Woodward et al., 1993). Eggs used in experiments with $S$. invicta were collected from two partially flooded nests at risk of total loss due to inundation. The remaining viable eggs from these nests (18 and 12 , respectively) were incubated separately from all other collected eggs, and monitored closely when they approached full term (see Woodward et al., 1989 for collection and incubation techniques). When initial pipping was noted, eggs were transferred to facilities at the United States Department of Agriculture (USDA) Imported Fire Ant Laboratory, Gainesville, Florida. The clutches pipped approximately two weeks apart, and each clutch was divided randomly into a control and a treatment group.

Two days before the estimated hatch date of viable eggs from clutch $\mathrm{A}$, we collected ten entire S. invicta colonies from Alachua County, Florida. Colonies were placed in 19-L plastic buckets simulating alligator nests with natural nesting material. Colonies were not collected directly from alligator nests because of logistical difficulties. It was important to collect entire colonies of $S$. invicta because worker behavior changes when queen(s) and brood are rot present (Stringer et al., 1976). Solenopsis invicta colonies were maintained at the USDA Imported Fire Ant Laboratory; Gainesville, Florida.

After transfer to USDA facilities, treatment eggs were placed in alligator nesting material in $19-\mathrm{L}$ buckets containing the viable colonies of S. invicta. Control eggs were transferred to identical 19-L buckets with nesting material but with no S. invicta. Each clutch was divided into three control and three treatment groups. For clutch $A$, three eggs were placed in each bucket. For clutch B, five eggs were placed in each bucket. Eggs were monitored closely during pipping. When a hatchling liberated itself from its egg, the alligator was removed from the bucket and placed in water, simulating liberation from the nest by the adult female alligator.

After all eggs in a clutch pipped, the hatchlings were removed from USDA facilities and transferred to Florida Cooperative Unit alligator incubation/rearing facilities located at the Florida Game and Fresh Water Fish Commission (GFC) Gainesville Research Laboratory. Alligators were weighed on the day of hatching and web tagged in both hind feet with sequentially numbered \#1 Monel tags (National Band and Tag Co., Newport, KY). Treated and untreated members of a clutch were combined and maintained in Unit facilities. Hatchling alligators were fed extruded pelletized alligator feed ad libitum. Alligators were weighed at four weekly intervals. During each weighing period, alligators were visually inspected for scarring or other effects of S. invicta envenomization. Handling of alligators was limited to weekly weighing and was minimized as much as possible during those periods. Body mass was determined with a hand-held $200 \mathrm{~g}$ spring scale accurate to $0.1 \mathrm{~g}$. After cessation of the experiment, surviving alligators were released at their original nest sites. We pooled clutches and used a repeated measures analysis of variance on body mass with body mass at time of treatment as a covariate (SAS Institute Inc., 1989).

We tested whether eggs of the American alligator were attractive food sources for S. invicta prior to pipping by utilizing nonviable eggs collected from nests on Lake Apopka. These eggs $(\mathrm{N}=20)$ were placed in colonies of $S$. invicta maintained in $61 \mathrm{~cm} \times 36 \mathrm{~cm} \times$ $13 \mathrm{~cm}$ bus trays at USDA facilities. Eggs were observed daily to see if they were breached by $S$. invicta.

On average, hatchling alligators took about $15 \mathrm{~min}$ to complete the hatching process. Two animals exposed to $S$. invicta died. The first death occurred within five minutes of hatching. In that instance, the alligator was slow in pipping and had difficulty escaping from its egg. As a result, that alligator received numerous fire ant stings $(>30)$. The second death occurred six days after treatment, just prior to the second weighing. That specimen was cannibalized before discovery, and the proximate cause of death could not be determined. All animals in the control group survived to release. Non-lethal injuries as a result of $S$. invicta stings were apparent in approximately $50 \%$ of experimental animals, and included swelling of extremities, especially digits, and visible pustules on the digits and around the eyes, where most stings occurred.

On the day of treatments, body mass did not differ between treated and control groups $(P>0.50)$. One week post-treatment, body mass differed between these two groups $(P=0.013)$. This difference in body mass remained consistent (week $2, P=0.09$; week 3 , $P=0.006$ ) for the three week period of this study (Fig. 1). An overall treatment effect was present $(P=0.002)$, but there were no significant time effects or interactions $(P>0.10)$. 


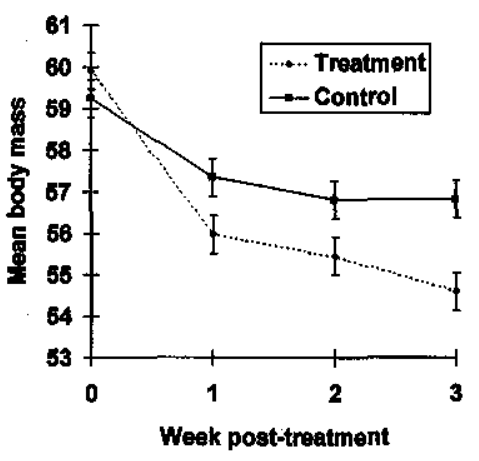

FIG. 1. Mean alligator body mass $( \pm 1$ standard error) in grams over time. Treatment animals hatched in the presence of red imported fire ant colonies.

Non-viable eggs placed in S. invicta colonies were not breached if the eggs were completely intact. Eggs with any type of irregularities on their surface or any hairline fractures were breached and consumed by $S$. invicta. The contents appeared to be an attractive food source for $S$. invicta.

Our results should be viewed as conservative. During incubation the outer shell of most alligator eggs begins to crack because of swelling and degradation as early as two weeks before pipping (Joanen, 1969), allowing fire ants prolonged access to egg contents. Cracked eggs are supported only by the inner egg membrane, a soft covering that is readily breached by S. invicta. Embryos and albumen of alligator eggs were an attractive food source for $S$. invicta in our experiments with non-viable eggs. Additionally, the necrotic action of S. invicta venom could lead to secondary infections affecting survival.

Pipping alligators were invariably stung when $S$. invicta colonies were present. Whether this was a defensive behavior because of the disturbance of the $S$. invicta colonies during pipping or whether the response was oriented towards resource acquisition could not be determined. That vertebrates may be preyed upon by $S$. invicta has been well documented (Allen et al., 1994). Population level impacts on vertebrates also have been demonstrated (Allen et al., 1995), but much less evidence is available.

Past research concerning the impacts of S. invicta on vertebrates has centered on predation of newly hatched young and pipping birds. Giuliano et al. (1996) demonstrated indirect impacts of stings. In that study, four day old northern bobwhite chicks exposed to $S$. invicta had reduced survival and weight gain. Our results suggest that non-lethal impacts from $S$. invicta envenomization may occur in other wildlife species. Many species of oviparous herpetofauna laying eggs on land may be vulnerable to S. invicta (e.g., Landers et al., 1980; Mount, 1981; Mount et al., 1981).

Other research has centered on the direct mortality of young animals because of S. invicta. While also documenting this direct mortality, our research documents indirect effects of S. invicta envenomization. Indirect impacts may be equally or more important than direct impacts in some species. In alligators, the two gram $(\sim 5 \%)$ average difference in body mass may or may not affect long-term survival. However, reduced weight gain of juvenile animals can result in reduced survival in the wild (Brockelman, 1975; Congdon and Gibbons, 1985; Parker and Plummer, 1987; Grant, 1991). We suggest that effects may be more pronounced in smaller and less robust species.

This is the first experimental evidence documenting indirect impacts by S. invicta on herpetofauna. The results are probably applicable to other egg-laying reptile species. Of particular concern is the impact of $S$. invicta on hatchling sea turtles and other endangered species. The authors have documented S. invicta on sea turtle nesting beaches and in sea turtle nests even on remote islands in the Lower Florida Keys, Marquesas Keys, and Ten Thousand Islands in south and southwest Florida.

Anthropogenic land use change has decreased habitat for many reptile and amphibian species (Richards, 1993). Increasingly, remaining habitat is disturbed and fragmented increasing the attractiveness of these sites to S. invicta (Tschinkel, 1988). Furthermore, at both local (Wojcik, 1993) and regional (Cokendolpher and Phillips, 1989) scales, S. invicta populations and range are increasing. We believe that the population-level impact of S. imvicta on many vertebrates is chronic and incremental, and, as such, not readily obvious.

Acknowledgments.-We wish to thank A. Woodward of the Florida Game and Fresh Water Fish Commission for providing access to alligator eggs and incubation space. C. Abercrombie, G. Davidson, and P. Wilkinson provided assistance with egg collection and incubation. R. Boughton and A. Woodward reviewed an earlier draft of this manuscript. This study was approved by the University of Florida Animal Care and Use Committee. This paper is contribution No. R-05423 of the Florida Agricultural Experiment Station Journal Series, Institute of Food and Agricultural Sciences, University of Florida.

\section{LITERATURE CITED}

AlLEN, C. R., S. Demarais, AND R. S. LuTZ. 1994. Red imported fire ant impact on wildlife: an overview. Texas J. Sci. 46:51-59.

$\longrightarrow$, R. S. LUTz, AND S. DEMARAIS. 1995. Red imported fire ant impacts on northern bobwhite populations. Ecol. Applic. 5:632-638.

BROCKELMAN, W. Y. 1975. Competition, the fitness of offspring, and optimal clutch size. Amer. Natur. 109:677-699.

COKEnDOlPHeR, J. C., AND S. A. Phillips, JR, 1989. Rate of spread of the red imported fire ant, Solenopsis invicta (Hymenoptera: Formicidae) in Texas. Southwest. Natur. 34:443-449.

CongDON, J. D., AND J. W. GiBBONs. 1985. Egg components and reproductive characteristics of turtles: relationships to body size. Herpetologica 41:194205.

DeITZ, D. C,, AND T. C. HINES. 1980. Alligator nesting in north-central Florida. Copeia 1980:249-258.

Donaldson, W., A. H. Price, AND J. Morse. 1994. The current status and future prospects of the Texas horned lizard (Phrynosoma cornutum) in Texas. Texas J. Sci. 46:97-113.

FreEd, P. S., AND K. NeITMAN. 1988. Notes on predation on the endangered Houston toad, Bufo houstonensis. Texas J. Sci. 40:454-456.

Giuliano, W. M., C. R. Allen, R. S. Lutz, AND S. 
DEMARAIS. 1996. Effects of red imported fire ant exposure on northern bobwhite chick survival and body mass. J. Wildl. Manage. 60:309-313.

GraNT, M. C. 1991. Relationships between egg size, chick size at hatching, and chick survival in the whimbrel, Numenius phaeopus. Ibis 133:127-133.

Hines, T. C., AND C. L. AberCrombie III. 1987. The management of alligators in Florida. In G. J. W. Webb, S. C. Manolis, and P. J. Whitehead (eds.), Wildlife Management: Crocodiles and Alligators, pp. 43-47. Surrey Beatty and Sons Pty Limited, Chipping Norton, New South Wales Australia.

JOANEN, T. 1969. Nesting ecology of alligators in Louisiana. Proc. Ann. Conf. Southeast. Assoc. Game Fish Comm. 23:141-151.

, AND L. MCNEASE. 1987. The management of alligators in Louisiana, USA. In G. J. W. Webb, S. C. Manolis, and P. J. Whitehead (eds.), Wildlife Management: Crocodiles and Alligators, pp. 3342. Surrey Beatty and Sons Pty Limited, Chipping Norton, New South Wales Australia.

LANDERS, J. L., J. A. GARNER, AND W. A. MCRAE. 1980. Reproduction of gopher tortoises (Gopherus polyphemus) in southwestern Georgia. Herpetologica $36: 353-361$.

MAZZOTTI, F. J., AND L. A. BRANDT. 1994. Ecology of the American alligator in a seasonally fluctuating environment. In S. Davis and J. Ogden (eds.), Everglades: the Ecosystem and its Restoration, pp. 485-505. St. Lucie Press, Delray Beach, Florida.

MONTGOMERY, W. B. 1996. Predation by the fire ant, Solenopsis invicta, on the three-toed box turtle, Terrapene carolina triunguis. Bull. Chicago Herpctol. Soc. 31:105-106.

MouNT, R. H. 1981. The red imported fire ant, Solenopsis invicta, (Hymenoptera: Formicidae), as a possible serious predator of some native southeastern vertebrates: direct observations and subjective impressions. J. Alabama Acad. Sci. 52:71-78.

, S. E. TRauth, AND W. H. Mason. 1981. Predation by the red imported fire ant, Solenopsis invicta, (Hymenoptera: Formicidae), on eggs of the lizard, Cnemidophorus sexlineatus (Squamata: Teiidae). J. Alabama Acad. Sci. 52:66-70.

PARKer, W. S., AND M. V. Plummer. 1987. Population ecology. In R. A. Seigel, J. T. Collins, and S. S. No- vak (eds.), Snakes: Ecology and Evolutionary Biology, pp. 253-301. MacMillian Publ.; Co., New York.

Pedersen, E. K., W. E. GRANT, AND M. T. LONGNeCKER. 1996. Effects of red imported fire ants on newly-hatched northern bobwhite. J. Wildl. Manage. 60:164-169.

RICHARDS, J. F. 1993. Land transformations. In B. L. Turner, II, W. C. Clark, R. W. Kates, J. F. Richards, J. J. Mathews, and W. B. Meyer (eds.), The Earth as Transformed by Human Action, pp. 164-178. Cambridge University Press, UK.

SAS INSTITUTE INC. 1989. SAS/STAT User's Guide. SAS Inst., Cary, North Carolina.

STRINGER, C. E., JR., W. A. BANKS, B. M. GLANCEY, AND C. S. LOFGREN. 1976. Red imported fire ants: capability of queens from established colonies and of newly-mated queens to establish colonies in the laboratory. Ann. Entomol. Soc. Amer. 69:10041006.

TSCHINKEL, W. R. 1988. Distribution of the fire ants Solenopsis invicta and $S$. geminata (Hymenoptera: Formicidae) in northern Florida in relation to habitat and disturbance. Ann. Entomol. Soc. Amer. 81: 76-81.

VINSON, S. B., AND A. A. SORENSEN. 1986. Imported fire ants: life history and impact. Texas Dep. of Agric., Austin, Texas.

WiLSON, E. O., AND J. H. EADS. 1949. A report on the imported fire ant Solenopsis saevissima var. richteri Forel in Alabama. Spec. Rep. to the Alabama Dept. of Conservation, Montgomery, Alabama.

WOJCIK, D. P. 1993. Impact of the red imported fire ant on native ant species in Florida. In D. F. Williams (ed.), Exotic Ants: Biology, Impact, and Control of Introduced Species, pp. 269-281. Westview Press, Boulder, Colorado.

WoOdward, A. R., M. L. JenNings, AND H. F. PerCIVAL. 1989. Egg collecting and hatch rates of American alligator eggs in Florida. Wildl. Soc. Bull. 17: 124-130.

- H. F. Percival, M. L. Jennings, AND C. T. MOORE. 1993. Low clutch viability of American alligators on Lake Apopka. Florida Sci. 56:52-63.

Accepted: 29 January 1997. 